\title{
Estimated enhancement of fish production resulting from restoring oyster reef habitat: quantitative valuation
}

\author{
Charles H. Peterson ${ }^{1, *}$, Jonathan H. Grabowski ${ }^{1}$, Sean P. Powers ${ }^{2}$ \\ ${ }^{1}$ Institute of Marine Sciences, University of North Carolina at Chapel Hill, Morehead City, North Carolina 28557, USA \\ ${ }^{2}$ Department of Marine Sciences, University of South Alabama and Dauphin Island Sea Lab, Dauphin Island, Alabama 36528, USA
}

\begin{abstract}
We reviewed studies providing quantitative measurements of abundance of fishes and large mobile crustaceans on oyster reefs and on nearby sedimentary habitat in the southeast United States. For each species, we compared density by size (age) class on oyster reefs and sedimentary bottom as a means of estimating the degree to which restoration of oyster reef on sedimentary bottom could augment abundances. By applying published information on growth rates of each species and a combination of empirical data and published information on age-specific survivorship, we calculated the per-unit-area enhancement of production of fishes and large mobile crustaceans expected from the addition of oyster reef habitat. For this calculation, we gave the reef habitat full credit for the expected lifetime production of species whose recruitment was judged to be limited by the area of oyster reefs based on nearly exclusive association of recruits to reefs. For species that were only modestly enhanced in abundance by oyster reefs, we gave the reef credit for the fraction of production that is derived from consumption of reef-associated prey, using a combination of gut content data and natural history information. This combination of analyses and calculations revealed that $10 \mathrm{~m}^{2}$ of restored oyster reef in the southeast United States is expected to yield an additional $2.6 \mathrm{~kg} \mathrm{yr}^{-1}$ of production of fish and large mobile crustaceans for the functional lifetime of the reef. Because the reef is biogenic and self-sustaining, the lifetime of a reef protected from bottom-disturbing fishing gear is limited by intense storms or sedimentation. A reef lasting 20 to $30 \mathrm{yr}$ would be expected to augment fish and large mobile crustacean production by a cumulative amount of 38 to $50 \mathrm{~kg} 10 \mathrm{~m}^{-2}$, discounted to present-day value. This set of calculations assumes that oyster reef habitat now limits production of reef-associated fish and crustaceans in the southeast United States. This assumption seems reasonable based on the tight associations of so many fishes with reef-dependent prey, and the depletion of reef habitat over the past century.
\end{abstract}

KEY WORDS: Habitat restoration · Oyster reef · Fish production · Mitigation · Restoration scaling · Essential fish habitat

Resale or republication not permitted without written consent of the publisher

\section{INTRODUCTION}

The application of ecology to achieve explicit goals in conservation and restoration represents a challenge to the discipline, and typically demands novel syntheses of relevant data and conceptual theory (Carpenter \& Kitchell 1993, Peterson 1993, Lawton 1996). Because of societal demands to compensate for growing degradation of natural resources on land (Vitousek et al.
1997) and in the sea (Botsford et al. 1997), recent growth in the practice of restoration has been so dramatic that restoration ecology is anticipated to become a dominant focus of environmental science of the new century (Wilson 1992, Hobbs \& Harris 2001). Ecological restorations have generally proceeded faster than the development of the theoretical and conceptual bases which support them (Allen et al. 1997, Palmer et al. 1997, van Diggelen et al. 2001). While the history of 
restoration of wetlands, terrestrial plant systems, salt marshes, and seagrass beds is relatively long (Jordan et al. 1987, Thayer 1992), restoration of marine biogenic habitats created by animals, such as corals, oysters, mussels, polychaetes, and vermetid gatropods, is a new development (Coen \& Luckenbach 2000). For oyster reefs, even their wide recognition as an important biogenic habitat rather than merely a commodity to exploit is very recent (Lenihan \& Peterson 1998).

Oyster reef habitat provides numerous important ecosystem services, which have only recently been documented and quantified. Oyster reefs serve as important biogenic habitat for benthic invertebrates (Wells 1961, Zimmerman et al. 1989) as well as fishes and mobile crustaceans (Bahr \& Lanier 1981, Breitburg 1999, Coen et al. 1999, Lenihan et al. 2001). Through their filtration activities, oysters and other suspensionfeeding bivalves also help counteract impacts of estuarine eutrophication (Jackson et al. 2001). Feeding oysters remove suspended inorganics, phytoplankton, and detrital particles, thereby reducing turbidity and improving water quality (Dame 1996). Biodeposits from feces and pseudofeces of oysters accumulate around reefs and induce denitrification (Newell et al. 2002). Oyster reefs sequester carbon in the form of calcium carbonate of the accumulating shell matrix (Hargis \& Haven 1999), and thus contribute to global carbon budgets. Through their removal of organic particles in the water column, oysters divert energy to benthic food chains and depress pelagic energy flows that may otherwise lead to noxious sea nettles (Newell 1988). Furthermore, the physical structure of a fringing oyster reef can serve to protect salt marsh habitat by dissipating erosive wave energy (Meyer et al. 1996). Oysters and the reefs that they build have been depleted dramatically in many estuaries of the southeast USA and the world (Rothschild et al. 1994, Lenihan \& Peterson 1998), motivating restoration efforts.

In part because of the short history of recognition of oyster reefs as important fish habitat, no estimates have been generated of how much additional fish production might be reasonably expected from restoring an oyster reef. Such an understanding is important in designing restoration projects to compensate for losses in fish production from chemical spills or some other environmental incident. In the USA, the National Oceanographic and Atmospheric Administration (NOAA) and other natural resource trustees use 'habitat equivalency analysis' to determine how to scale a restoration project to match, and therefore compensate for, the quantified injury to natural resources (e.g. NOAA 1997, Fonseca et al. 2000). This process seeks to replace lost ecosystem services, which are commonly based upon the lost production of higher trophic levels, such as fish and large mobile crustaceans. Losses include not only the biomass killed but also the interim losses associated with production foregone that would have been expected had those individuals been able to live their full natural life spans (French 1999).

Quantifying the expected enhancement of production by fish and large mobile crustaceans from creation of an oyster reef requires consideration of some of the most fundamental questions in fisheries ecology. First, one must address whether the recruitment of any species of fish is limited by the extent of available reef habitat. If addition of reef habitat serves to overcome a survival bottleneck in the early life history of any species, then installation of additional reefs would promote a numerical response of enhanced recruitment in those species. Because oyster reef habitat has declined dramatically by 2 orders of magnitude in many estuaries of the southeastern USA (Rothschild et al. 1994, Lenihan \& Peterson 1998), we assume that any species exhibiting greatly enhanced abundance of recruits on reefs, relative to nearby unstructured sedimentary habitats, is limited in recruitment by oyster reef area. By recruitment, we adopt the marine ecologists' usage referring to individuals surviving early post-settlement mortality to a size that can be reliably censused (Doherty \& Williams 1988). Second, new reefs may enhance fish production by providing spatial refuges from predation and alleviating food limitation through producing reef-associated prey resources. This response then enhances fish production, not by adding new fish to the system, but rather by enhancing survival and subsidizing growth of individuals already present in the regional population and thereby producing gains in fish production. The enhanced survival that may result from provision of structural refuges from predation (Hixon 1998) is incorporated into both of these measures of reef impact on fish production, because enhanced densities of both recruits and older fishes on reefs reflect effects of the reef on survival.

Here we utilize these concepts of habitat and food limitation on fish production on oyster reefs to estimate the augmented production of fish and large mobile crustaceans expected per unit area of created oyster reef. We focus our analysis on southwest Florida to develop information that would allow compensation for losses of fish production arising from an acidic process water spill in a Tampa Bay tributary. Losses of production by fish, shrimp, and crabs from that spill had been determined by sampling the numbers of dead organisms of each species by age class to estimate the immediate loss of biomass, and then using published survival and age-specific growth curves to calculate the future production foregone by their untimely loss (French 1999). We follow this same approach of calculating the ecosystem service of fish production provided by installation of oyster reefs so as 
to allow losses to be matched to gains from restoration in an identical currency (a habitat equivalency analysis: Fonseca et al. 2000). To develop our estimates, we draw upon data from available published and gray literature from the southeast USA, thereby rendering the calculations applicable to a broad biogeographic region. This approach should be transferable to quantifying oyster reef services elsewhere.

\section{MATERIALS AND METHODS}

Overview. To quantify the enhancement in fish and mobile crustacean production expected per unit area of added oyster reef habitat, we adopted the following procedure (Fig. 1) to estimate the contributions by (1) species limited in recruitment by habitat area (termed recruitment-enhanced), and (2) species limited in production by reef refuges from predation and available food (growth-enhanced). We synthesized results of available empirical, quantitative studies from the southeast USA to estimate the magnitude of density enhancement for each species of fish and mobile crustacean on oyster reefs relative to unstructured sedimentary habitat. First, species showing no numerical association with reefs made no contribution to our estimate of enhancement of fish production by reefs. Second, we identified species whose recruitment was habitat-limited based on nearly exclusive association of recruits with oyster reefs instead of mud/sand habitat, and on life-history information indicating obligate association with structural features of benthic habitat. The remaining species formed a third class that was not limited in recruitment by reef habitat but whose growth and survival was limited by reef-associated resources, as judged by significant augmentation of abundance on oyster reefs as opposed to mud/sand habitats. We then calculated the average augmentation of abundance per unit reef area by species and by age class within species. Published species-specific growth and survivorship parameters were then used to convert the augmented abundance by age class into expected enhancement of lifetime production for each species. For each species judged not to be limited in recruitment by reef area, but instead limited in production, we used dietary information to calculate an index of reef exclusivity in feeding so as to credit the oyster reef for only that fraction of growth derived from

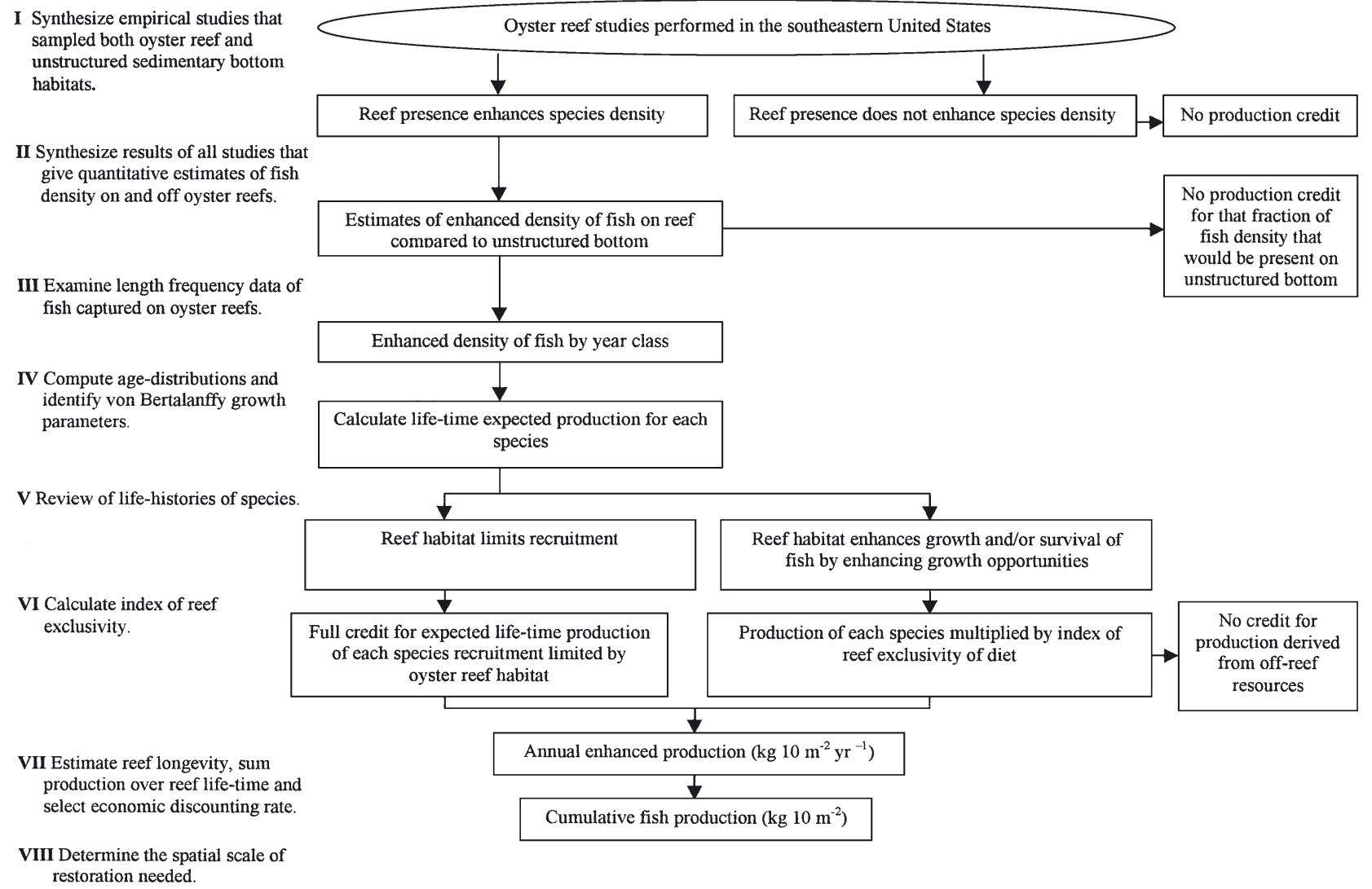

Fig. 1. Flow diagram illustrating our approach to calculating expected enhancement of fish and mobile crustacean production resulting from the restoration of oyster reefs in the southeastern USA 
reef-associated prey. Partitioning growth by prey source helps address the long-standing question of whether reefs simply aggregate fish or increase their production by providing reef-associated prey resources (Bohnsack 1989). We then summed these reefdependent enhancement estimates across all species to produce the total expected enhancement of fish and crustacean production per unit reef area. Finally, economic discounting was applied to amend these calculations to account for the time value of resources and services in matching resource loss to resource gain through creation of oyster reefs.

Synopsis of studies. Six studies conducted in the southeastern USA (Fig. 2) formed the basis of our synthesis (Table 1). Zimmerman et al. (1989) used $2.6 \mathrm{~m}^{2}$ circular drop samplers to quantify animals that use shallow, subtidal oyster reefs and adjacent sand/mud habitats in the West Bay region of Galveston Bay, Texas. Wenner et al. (1996) quantified fish and mobile crustaceans on both restored and natural oyster reefs near Charleston Harbor, South Carolina. Their study used $3.2 \mathrm{~mm}$-mesh lift nets, which were folded and buried along the perimeter of oyster reef and then raised on a falling tide to enclose the entire area $\left(24 \mathrm{~m}^{2}\right)$. Meyer et al. (1996) used block and fyke nets to quantify fish and mobile crustaceans in 3 Spartina marsh-edge habitats (bordered by restored oyster reef, natural oyster reef or unstructured bottom) at each of 3 sites in North Carolina. Two block nets (19.3 m long $\times 1.3 \mathrm{~m}$ high with $3.2 \mathrm{~mm}$ mesh) were positioned perpendicular to the shoreline, and a $1.3 \mathrm{~m}$ high fyke net

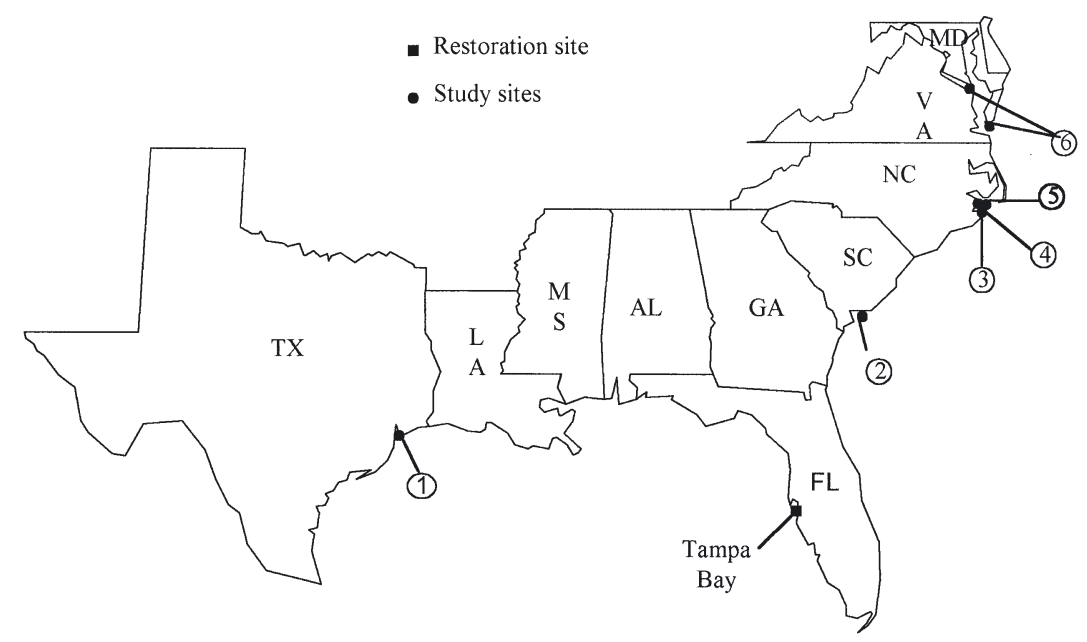

Fig. 2. Southeastern USA, with the sites of empirical studies used in our synthesis noted by filled circles and the targeted restoration site, Tampa Bay, FL, noted by the filled square. Numbers identify the location and sources of data: (1) Galveston Bay, TX, Minello \& Zimmerman (1989); (2) Charleston Harbor, SC, Wenner et al. (1996); (3) Back Sound, NC, Grabowski (2002); (4) Back Sound, White Oak River and New River, NC, Meyer et al. (1996); (5) Neuse River and Pamlico Sound, Lenihan et al. (1998, 2001); and (6) Chesapeake Bay, VA, Mann \& Harding $(1997,1998)$, Harding \& Mann (1999), O'Beirn et al. (1999) with $3 \mathrm{~m}$ wings was placed along the $5 \mathrm{~m}$ long, lowtide mark. Nets were set on a falling tide and animals collected at low tide. Grabowski (2002) used a variety of sampling gear (gill nets, crab traps, fish traps, minnow traps, and $1 \mathrm{~m}^{2}$ colonization trays filled with oyster shell) to sample fish and mobile crustaceans on restored intertidal oyster reef and nearby unstructured bottom in Back Sound, North Carolina. Lenihan et al. (1998, 2001) used the same gear as Grabowski (2002), along with visual observations, to sample restored and natural oyster reefs and nearby sand/mud bottom in subtidal areas of the Neuse River estuary and West Bay, Pamlico Sound, North Carolina. Finally, investigators at the Virginia Institute of Marine Sciences (VIMS: Mann \& Harding 1997, 1998, Harding \& Mann 1999, O'Beirn et al. 1999) sampled fish and mobile crustaceans by otter trawl and gill nets at a large $(210 \times$ $30 \mathrm{~m}$ ) restored oyster reef and $2 \mathrm{mud} / \mathrm{sand}$ flats in the Piankatank River, Virginia, and at several smaller restored reefs and unstructured bottom areas near Fisherman Island at the mouth of Chesapeake Bay.

Relative enhancement estimates. To evaluate the questions of whether and to what degree a species abundance was enhanced by the presence of oyster reef, we used only those 5 studies that sampled fish and mobile crustaceans both on oyster reef and on adjacent unstructured habitat (Zimmerman et al. 1989, Meyer et al. 1996, Lenihan et al. 1998, 2001, the VIMS studies [see above], and Grabowski 2002). We compiled data on comparisons of fish and mobile crustacean catches on oyster reefs to nearby unstructured bottom. The results from each of the 5 studies were then summarized into 1 database that computed the ratio of catch on-reef to catch off-reef for each sampling period by gear type (see Table 5). When a ratio could not be calculated because a species occurred in a single habitat, that fish or mobile crustacean was designated as 'all reef ' or 'all mudflat'. A species was judged to be enhanced in abundance by the presence of an oyster reef if a majority of studies either had index values above 1 or indicated 'all reef' (see Table 5). In cases where only 1 study reported data for a given species, we used the more conservative threshold of $>2$ to declare a species enhanced by reef presence.

We next assigned each species of fish and crustacean judged to be enhanced by the presence of oyster reef to 1 of our 2 conceptual groupings: (1) recruitmentenhanced and (2) growth-enhanced 


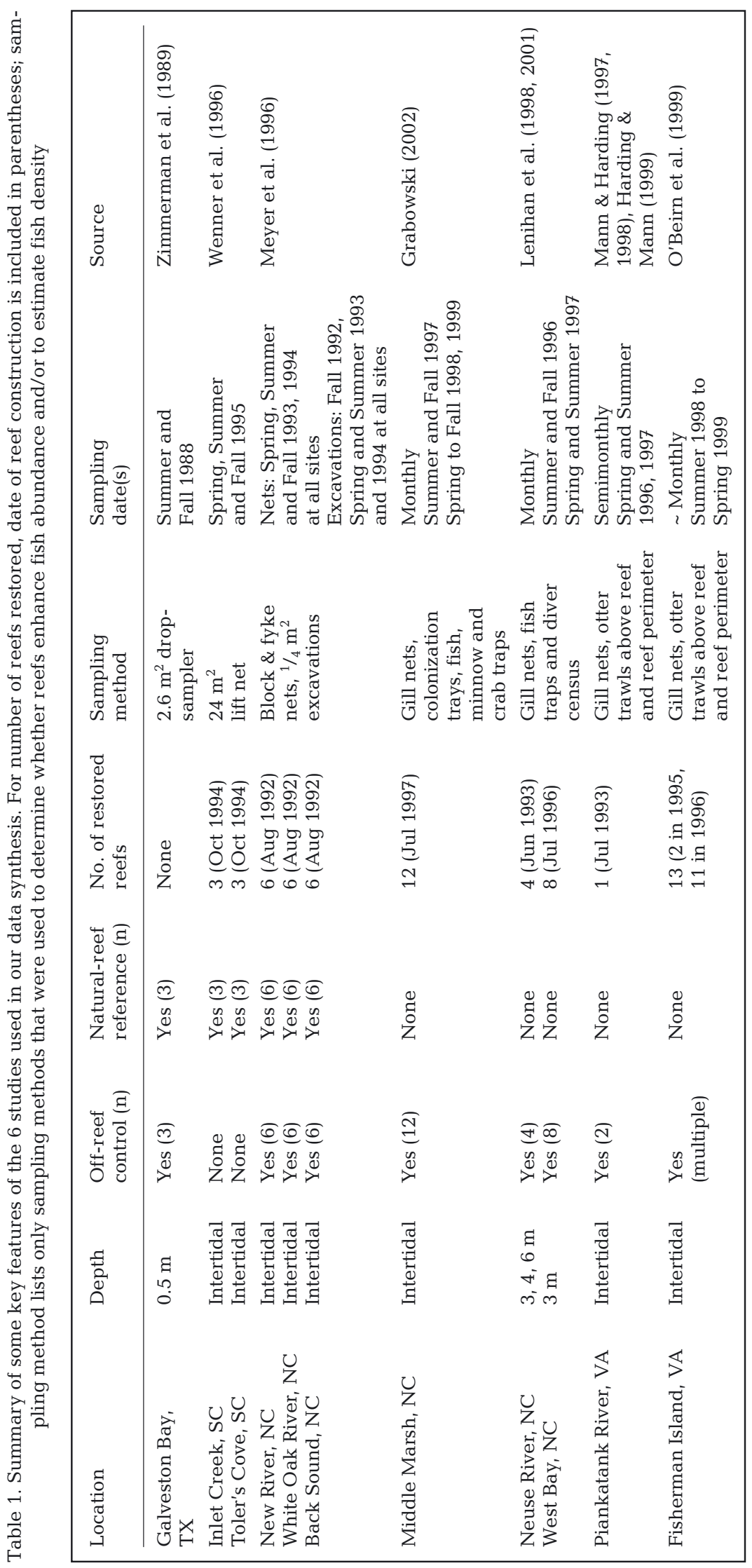

species. Our distinction between these 2 classes was based on the magnitude of enhancement as well as a careful review of life-history information. Our practice was to assign demersal species that had nearly exclusive occupation of oyster reefs as recruits (demonstrated by a majority of studies characterizing that species as 'all reef') to the first group, and those demersal species that showed more moderate enhancement plus pelagic species showing all levels of enhancement to the second group.

Because comparisons of catches occurred between 2 different habitats, we must consider potential differential biases in sampling efficiency between habitats (sensu Peterson \& Black 1994). Crab pots, fishtraps, minnow pots, and colonization trays constitute structural elements: fish may be attracted to such structures in greater numbers in an unstructured environment than in a highly structured one (Sheaves 1992). Any bias of this nature would result in a more conservative estimate of our enhancement ratio. Similarly, any biases in trawling would tend to produce artificially low catches of animals on reefs because of the difficulty of towing trawls over highly structured reef areas.

Density estimates. After we had determined that a particular species was enhanced in abundance by the presence of oyster reef habitat, we then assessed whether that species or a close ecological counterpart occured at the targeted restoration site, Tampa Bay, Florida (using faunal listings in Livingston 1984, 2001, Lewis \& Estevez 1988). Next, we addressed the issue of sampling efficiency for each gear type used in the 6 studies. Of these studies, only Zimmerman et al. (1986, 1989) and Wenner et al. (1996) tested gear efficiency against a known standard number of fish and invertebrates. Zimmerman et al. (1986) found that recovery efficiency of their $2.6 \mathrm{~m}^{2}$ drop samplers was $96 \%$ for small invertebrates. Efficiency of lift nets in Wenner et al. (1996) ranged from 54 to $68.5 \%$ for a small benthic fish (mummichog) and 43 to $54 \%$ for a benthic invertebrate (grass shrimp). Testing a similar lift net, Rozas (1992) had previously shown catch efficiencies of 32 to $93 \%$. Because these methods demonstrated relatively high sampling efficiencies and wide ranges among and within species, we did 
not use any correction factor for densities measured with drop samplers or lift nets.

One of 2 alternative procedures was employed to estimate the quantitative enhancement on a per-unitarea basis for each species whose abundance was judged to be enhanced by oyster reefs. For those species collected by Zimmerman et al. (1989) and/or Meyer et al. (1996) that sampled a defined area, we used their estimates (averaged across studies for any species that appeared in both studies) of absolute density on and off reefs. For reef-enhanced species that were not collected in Zimmerman et al. (1989) or Meyer et al. (1996), estimates were derived from trap catches in Lenihan et al. (2001) and Grabowski (2002) and converted to densities. The 'habitat traps' or 'M-traps' used by Lenihan et al. (2001) and Grabowski (2002) lacked standardization to the area sampled. Thus, to convert their data on differences between average catches on reefs and sand/mud flats to density enhancement per unit area, we standardized abundances of fish caught on reefs in traps by the observed densities on reefs in lift nets taken from Wenner et al. (1996) for gray snapper and pigfish (pooled), species common to all 3 studies. The resulting conversion factor was applied to transform catches in traps to densities. For example, if the average density (from Wenner et al. 1996) of gray snapper plus pigfish on reefs is $x$, and the average numbers per habitat trap on reefs is $y$, then the conversion factor would be $x / y$. The VIMS studies were not used for density calculations because, for all species judged to be enhanced by oyster reefs, quantitative data existed in the other studies at sites geographically closer and environmentally more similar to the Tampa Bay restoration area.

To determine the expected enhancement of density for each species by oyster reef presence, we subtracted our off-reef average density from our on-reef density estimate. The rationale was that the off-reef density represents fish that would be present in the absence of reef habitat, and that the reef should be credited only for the enhancement of fish. With the exception of blennies, gobies and silversides, which consist of multiple species within each group, we calculated density enhancement by species. Because of similarity in life history, mortality rate, and functional niche, and differences in biogeographic ranges of sibling species, we grouped blennies, gobies, and silversides into 3 taxa. In estimating density enhancements, we chose to use data from the date of peak density for each species, which consistently occurred in summer or early fall. We averaged these seasonal maxima across studies (except for 3 species that occurred in only a single study) to provide density estimates reflective of the time of peak recruitment and utilization of the estuarine habitats.
Age distributions of fish on reefs. Once the estimate of enhanced density $(N)$ was calculated for a given species, we determined how various age classes (i) contributed to that density (Table 2). Using published estimates of annual growth for each species (Table 3), we partitioned available length-frequency data of fish on reefs by age class $\left(N_{i}\right)$. This process sufficed for 3 taxa of small fishes that are readily caught and whose densities through all age classes are well estimated by lift nets (Table 2). For taxa ( 7 of the 11 total species that are not annuals) in which our quantitative sampling only provided reliable density estimates of 0 yr class individuals, we calculated expected abundances of older age classes based on (1) the known numbers of 0 yr-old recruits measured in the empirical studies, and (2) published estimates of their annual mortality rate (Table 3). We assumed that the distribution of age classes follows a stable age distribution, if annual mortality rate remains constant, using the formula:

$$
S_{i}=S_{0} \times \mathrm{e}^{\left(-M_{i} \times i\right)}
$$

where $S_{i}$ is the proportion of individuals in age class $(i-1)$ surviving to age class $i$, and $M$ is the natural mortality rate for age class $i$. For species that are fished, mortality rate does not remain constant with age, but increases by the rate of fishing mortality $(F)$ added at the age of first harvest $(r)$. Thus, for harvested species, $S_{i}$ was computed using Eq. (1) until $i>r$, when:

$$
S_{i}=S_{r} \times \mathrm{e}^{\left[-\left(M_{i}+F_{i}\right)(i-r)\right]}
$$

The density of fish in age class $i\left(N_{i}\right)$ was then determined by multiplying $N_{(i-1)}$ by the survival rate $\left(S x_{i}\right)$ for i, calculated by using $S_{i}$ and $S_{(i-1)}$ from either Eq. (1) or (2), by

$$
S x_{i}=S_{i} / S_{(i-1)}
$$

Table 2. Age classes observed in density estimates from field sampling for those species or species groups determined to be enhanced by oyster reef. Blenny and goby species are treated as annuals; consequently, only 1 age class was present in the population. The $0 \mathrm{yr}$ class includes fish from the time they recruit to their first birthday

\begin{tabular}{lc}
$\begin{array}{l}\text { Species or } \\
\text { species group }\end{array}$ & $\begin{array}{c}\text { Age (yr) class(es) included } \\
\text { in density estimate }\end{array}$ \\
\hline Sheepshead & 0 \\
Stone crab & 0 \\
Gray snapper & 0 \\
Gag grouper & 0 \\
Black sea bass & 0 \\
Spottail pinfish & 0 \\
Pigfish & 0 \\
Toadfish & 0,2 \\
Sheepshead minnow & All \\
Bay anchovy & All \\
Silversides & All
\end{tabular}




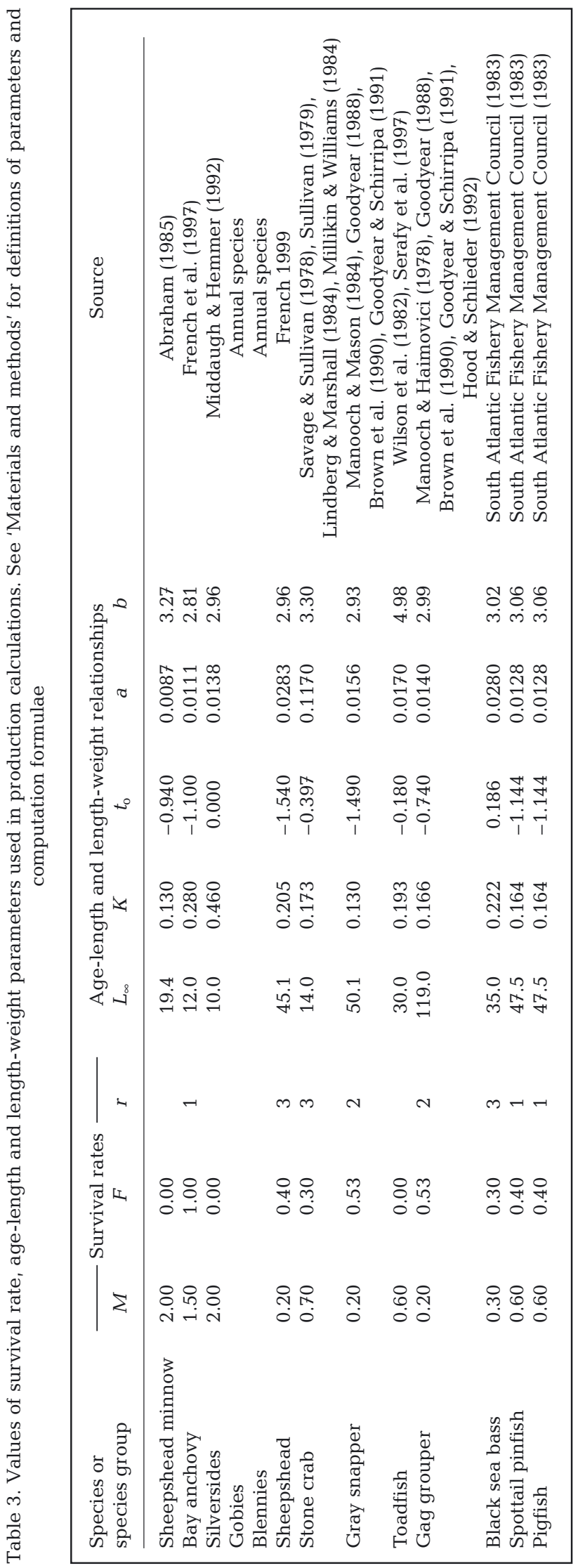

Using this calculation procedure, we compensate for the underestimation of density of larger, older fish by assuming that the expected numbers of older age classes are indeed present. This addition of ghost fish to our estimate of enhanced density makes the assumption that the older fish continue to utilize reef habitat, which was confirmed by both visual observations and gill net samples. For one species (toadfish), the quantitative sampling by traps and lift nets provided reliable estimates of densities of the first 3 age classes, but no fish in the remaining 5 age classes (Table 2). To estimate densities of these rarer, older age classes, we first applied the age-specific mortality rates to the sum of abundances of the 3 early age classes to compute the expected distribution of abundances among those 3 age classes. This computation allowed us to depreciate the numbers in the oldest (third) age class by applying the age-specific mortality schedule to estimate numbers of fish beyond age class 3 . The sum of numbers of fish in the 3 early age classes remained constant, but the total numbers were augmented by ca. $14 \%$ when older ghost fish were added.

Production calculations. We chose an area of $10 \mathrm{~m}^{2}$ over which to calculate our estimated enhancement of annual production of fishes and large mobile crustaceans by oyster reefs. Using our estimate of enhanced density in each age class, we quantified how much annual production each age class would be expected to achieve, and summed these production estimates over all ages to estimate total annual enhanced production for each species. Our computation assumed that the $0 \mathrm{yr}$-class recruits, assessed in most studies at an age of approximately $1 / 2 \mathrm{yr}$, would all survive to their first birthday. This overestimate of annual production by fish surviving from their half birthday to their first birthday is assumed to compensate for the failure to include estimates of production of those other fish in that same age cohort that had recruited to the reefs and grew to some size but died before sampling occurred on the half birthday. For annual species (gobies and blennies), we calculated annual production by multiplying average fish weight by the estimate of density enhancement. For all other species, we first calculated the average length at age $i$ $\left(L_{i}\right)$ using the von Bertalanffy growth equation:

$$
L_{i}=L_{\infty} \times\left\{1-\mathrm{e}^{\left[-K \times\left(i-t_{0}\right)\right]}\right\}
$$

where $L_{\infty}$ (the asymptotic maximum length), $K$ (the Brody growth coefficient), and $t_{0}$ (a constant representing the age at zero length) are derived from literature values for each species (Table 3). To convert $L_{i}$ to an average weight at age $i\left(W_{i}\right)$, we used the lengthweight relationship:

$$
W_{i}=a \times L_{i}^{b}
$$


where $a$ and $b$ are species-specific constants available from the literature (Table 3 ). The change in weight between successive age classes is equal to the annual production of an individual surviving through age class $i\left(P_{i}\right)$ :

$$
P_{i}=W_{i}-W_{(i-1)}
$$

We treated the 2 groups of fishes deemed 'enhanced by reef presence' differently, in calculating the enhanced annual production credited to the construction of $10 \mathrm{~m}^{2}$ of oyster reef. For recruitment-enhanced species, we credited their complete expected lifetime production to the reef, independent of whether they fed on reef-associated resources or even remained on the reef after recruitment. Our rationale is that these additional individuals that recruit to the reef would not be present in the population in the absence of the reef. Two of the augmented species, gag grouper and gray snapper, recruit to oyster reefs before migrating to offshore reefs to complete their adult lives. On the basis of the depletion of fish within the snapper-grouper complex on offshore reefs, we assume that adding to their populations by constructing oyster reefs and enhancing snapper-grouper recruitment does not lead to compensatory reductions in growth from food competition offshore. To account for the future production expected from the cohort of recruits sampled on the reef, we computed expected lifetime production using the method described above, adjusting each future year's contribution by a standardly applied $3 \%$ annual discount rate $(d)$ (NOAA 1997):

$$
P_{i} \times 1 /(1+d)^{i}
$$

Consequently, for gag grouper and gray snapper the annual production estimate for any year is the sum of the production of the 0 age class, plus its discounted future expected production.

For growth-enhanced species, we developed and applied an index of reef exclusivity (IRE) to weight the expected production of each of these species by the degree to which its growth is attributed to resources produced on the reef. If, for example, a species of fish merely aggregates behaviorally around the reef structure yet feeds entirely on prey from other habitats (e.g. sand bottom, water column), then it may be inappropriate to credit all its observed growth to the presence of the reef. Alternatively, if a species whose abundance is enhanced by reef presence forages exclusively on benthic or demersal resources that are produced on reefs, then its entire production should be credited to the new reef. Accordingly, we weighted the production credit for this category of fish species limited by reef resources by IREs ranging from 0.10 to 1.0 (Table 4). We used 0.10 as a minimum value to account for the likelihood that some fishes gain survival bene- fits from association with reef structure, despite foraging on soft-sediment or water-column resources (e.g. Lindquist et al. 1994). The index was constructed for each species from available gut content information (Mann \& Harding 1997, 1998, Grabowski 2002). For species lacking quantitative information on gut contents at a level of taxonomic discrimination that allowed reef-exclusive prey to be identified, we used life-history profiles and observed feeding behaviors to set the value of the index. The index primarily reflected a distinction between fishes feeding on benthic or demersal prey versus those feeding on planktonic prey, but it is further modified by the knowledge of whether the benthic prey themselves grow on reefs or on other substrata, such as sand and mud (Table 4).

Applying the IRE, total enhanced annual production for year $y\left(P_{Y}\right)$, attributable to the presence of $10 \mathrm{~m}^{2}$ of oyster reef for a particular species, was calculated by:

$$
P_{Y}=\operatorname{IRE} \times \sum\left(P_{i} \times N_{i}\right)
$$

For recruitment-enhanced species, the IRE was set to 1.0. For growth-enhanced species, the IRE ranged from 0.1 to 0.75 (Table 4). Finally, total annual enhancement of reef fish and large mobile crustacean production per $10 \mathrm{~m}^{2}$ of reef was expressed as the sum of $P_{Y}$ across all 13 species or species groups. We provide an example of the full set of calculations estimating expected enhancement of production for 1 species, sheepshead, to illustrate the sequence of operations (Appendix 1).

Discounting and scaling factors. The factor of time enters into valuation of ecosystem services from habitat or species restoration actions that are intended to compensate for natural resource losses. First, although replacement of lost resources by restoration of like or similar resources does not involve translation into dollar values, the time cost of lost resources enters into the process of establishing equivalency. By US federal guidance, a standard annual discount rate of $3 \%$ is applied to account for time delays between loss of resources or resource services and their restoration (NOAA 1997). Accordingly, we applied this discount rate to convert any future expected gain in fish production from reef restoration into present-day value.

Time also enters into the process of assessing the rate of establishment of ecosystem services following initiation of the restoration action. To address this issue, we examined the change in abundance of fish and large mobile crustaceans over time on restored oyster reefs (Wenner et al. 1996, Lenihan et al. 1998, Grabowski 2002). We also compared catches of mobile species on restored and naturally occurring reefs in those studies that included this contrast (Meyer et al. 1996, Wenner et al. 1996, Lenihan et al. 2001). Additionally, we evaluated changes in densities and composition of benthic prey (primarily small crustaceans) 
Table 4. Estimated enhanced density and production for the 13 species or species groups (2 goby, 2 blenny, and 3 silverside species are grouped because the species within each group exhibit similar life histories) that were more densely populated on oyster reef habitat than on unstructured sedimentary habitat. For sheepshead minnow, bay anchovy, and silversides, density augmentation estimates include all age classes. The density estimate for toadfish includes age classes 1 to 3 . Gobies and blennies $<1$ yr. All other species include estimates of young of year (YOY) only. Index of reef exclusivity (IRE) is an estimate of species utilization of food resources associated with oyster reef compared to resources from adjacent non-reef habitat; this is derived from comparison of the density of the species on and off the reef, gut content analyses where available, and life history profiles. (IRE is not calculated for species in the RE group because all production is attributed to the reef; for calculation purposes the IRE is set to 1.0) Grouping is assigned for augmented production estimates: RE = species that recruited exclusively to reefs (compared to unstructured mud/sand bottom) and were intimately associated with the reef structure - all production is attributed to the reef; $\mathrm{G}=$ these species showed aggregation around the reef but diet analyses and life history information did not indicate that these species were limited by reef habitat; however, these individuals probably have some augmented growth because of the presence of the reef structure/resources

\begin{tabular}{|c|c|c|c|c|}
\hline Species or species group & $\begin{array}{l}\text { Average increase of density } \\
\text { (ind. } 10 \mathrm{~m}^{-2} \text { ) }\end{array}$ & IRE & Grouping & $\begin{array}{l}\text { Annual increase in secondary } \\
\text { production }\left(\mathrm{kg} 10 \mathrm{~m}^{-2} \mathrm{yr}^{-1}\right)\end{array}$ \\
\hline Gobies (2 spp.) & 128.85 & - & $\mathrm{RE}$ & 0.644 \\
\hline Blennies (2 spp.) & 5.00 & - & $\mathrm{RE}$ & 0.050 \\
\hline Sheepshead & 1.04 & - & RE & 0.586 \\
\hline Stone crab & 25.77 & - & $\mathrm{RE}$ & 0.653 \\
\hline Gray snapper & 0.96 & - & $\mathrm{RE}$ & 0.114 \\
\hline Toadfish & 0.96 & - & $\mathrm{RE}$ & 0.022 \\
\hline Gag grouper ${ }^{a}$ & 0.16 & - & $\mathrm{RE}$ & 0.293 \\
\hline Black sea bass & 0.39 & 0.75 & G & 0.046 \\
\hline Spottail pinfish & 0.08 & 0.75 & G & 0.005 \\
\hline Pigfish & 4.22 & 0.75 & G & 0.135 \\
\hline Sheepshead minnow & 2.59 & 0.10 & $\mathrm{G}$ & 0.000 \\
\hline Bay anchovy & 158.80 & 0.10 & $\mathrm{G}$ & 0.019 \\
\hline Silversides (3 spp.) & 15.38 & 0.10 & $\mathrm{G}$ & 0.002 \\
\hline \multicolumn{4}{|c|}{ Total annual increase in fish production: } & 2.570 \\
\hline
\end{tabular}

over time in restored oyster reefs, and drew comparisons between natural and restored reefs. From this synthesis, we estimated the time to develop complete functional equivalence in fish and mobile crustacean production on a restored oyster reef as input to the valuation calculation.

Once the expected annual enhancement of fish and mobile crustacean production per unit area of restored oyster reef $\left(\mathrm{kg} 10 \mathrm{~m}^{-2}\right)$ has been calculated, including appropriate discounting to convert both losses and gains of production to present-day values, then scaling the size of the restoration project to a quantified production loss requires determination of the expected functional lifetime of the restoration. The longer the restoration successfully provides ecosystem services, such as living resource production, the smaller the spatial scale of the restoration that is required to achieve compensation. Given the uncertainty regarding the effects of storms (Livingston et al. 1999), adequacy of spawning stock biomass (Rothschild et al. 1994), water quality (Lenihan \& Peterson 1998, Lenihan et al. 2001), oyster diseases (Krantz \& Jordan 1996, Lenihan et al. 1999), and degradation of reef materials on oyster reef longevity, we calculated expected enhanced production values for several alternative project lifetimes. Our single best estimate of expected project lifetime was developed through consultation with other investigators in the southeastern USA, as well as our professional judgement. Once a project life span has been determined, the expected enhanced production attributable over the lifetime of a given area of restored habitat can be calculated, and the area of reef required to replace the total injury determined.

\section{RESULTS}

\section{Enhancement estimates}

Abundances of 19 species of fish and large mobile crustaceans were judged enhanced in abundance by the presence of oyster reef habitat. Based on the degree of observed density enhancement and life history, 10 were placed within the recruitment-enhanced group (Table 5). Included in this group were stone crabs, gag grouper, sheepshead, gray snapper, toadfish, tautog, feather blenny, striped blenny, and 2 species of gobies (skilletfish and naked goby). The remaining 9 species were classified as growthenhanced. This second group included black seabass, 
pigfish, southern flounder, spotail pinfish, sheepshead minnow, bay anchovy, and 3 species of silversides (rough, inland, and Atlantic).

The presence of oyster reef habitat probably enhanced the densities of 9 additional species; however, there were insufficient data either to provide compelling support for this conclusion or to resolve inconsistencies between studies. Five of these species (striped bass, white perch, weakfish, Atlantic spadefish, and butterfish) were collected in only a single study (striped bass and white perch in the VIMS studies; and weakfish, spadefish, and butterfish in Lenihan et al. 1998, 2001). Although catches were either higher on, or exclusive to, oyster reefs, low total numbers of these fishes failed to provide conclusive evidence of enhancement. White mullet was caught by Meyer et al. (1996) in high densities; however, the enhancement index value (1.8) did not exceed 2, our criterion for enhancement in a single study. Two species, red drum and spotted seatrout, exhibited conflicting evidence. Red drum were caught in both the VIMS and Grabowski (2002) studies: Grabowski's data indicated enhancement, whereas the VIMS studies caught red drum only away from reef sites. Spotted seatrout were collected in 2 studies: exclusively on oyster reefs in Grabowski (2002), but only on the sand/mud bottom in Zimmerman et al. (1989). This contradiction between studies may be explained by size-dependent changes in behavior. Zimmerman et al. (1989) collected small juveniles with drop samplers, whereas Grabowski (2002) caught larger adults with gill nets. Unfortunately, there were too few fish caught in either study to resolve the question. Size differences may also explain inconsistencies in blue crab data. In several studies with intense sampling effort, adult blue crabs caught in crab pots failed to show elevated densities on oyster reefs. However, in the VIMS studies, the only one reporting juvenile blue crabs separately from adults, blue crabs appeared to be enhanced by oyster reefs.

\section{Density estimates}

Of the 19 species judged to be enhanced by oyster reefs, 2 (tautog and summer flounder) are not reported in Tampa Bay, and have no obvious ecological equivalent. Numerically, pelagic bait-fish (bay anchovy, silversides, sheepshead minnow) and small demersal residents (gobies and blennies) accounted for the largest density enhancements among fishes (Table 4). Stone crabs, the only large mobile crustacean that exhibited compelling density enhancement, were also found in high densities. Longer-lived, commercially and recreationally exploited fish (sheepshead, gray snapper, black sea bass, gag grouper) were enhanced in abundance by oyster reefs but still remained at substantially lower densities than these bait-fishes, small demersals, and stone crabs (Table 4).

\section{Production estimates}

The 7 recruitment-enhanced species or species groups that occur in Tampa Bay account for the majority of the enhancement of production of fishes and mobile crustaceans (Table 4). Of the total enhanced production created annually by oyster reef restoration $\left(2.57 \mathrm{~kg} 10 \mathrm{~m}^{-2}\right), 92 \%$ is attributable to recruitmentenhanced species, whose recruitment is limited by reef area and whose production did not require adjustment by an IRE. Within this group, stone crabs $(0.653 \mathrm{~kg}$

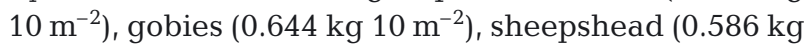
$\left.10 \mathrm{~m}^{-2}\right)$ and gag grouper $\left(0.293 \mathrm{~kg} 10 \mathrm{~m}^{-2}\right)$ account for most of the enhanced production. Those growthenhanced species and species groups whose recruitment did not appear limited by oyster reef area, but were credited for realizing enhanced production in the presence of reefs, account for the remaining $8 \%$ $\left(0.21 \mathrm{~kg} 10 \mathrm{~m}^{-2}\right)$ after the IRE was applied to production estimates. Production of pigfish $\left(0.135 \mathrm{~kg} 10 \mathrm{~m}^{-2}\right)$ and black seabass $\left(0.046 \mathrm{~kg} 10 \mathrm{~m}^{-2}\right)$ represent the majority of the production from this second group. Along with spottail pinfish, these species derive the majority of their food from the reef (IRE $=0.75$ ). For baitfish (bay anchovy, silversides, sheepshead minnow), the IRE was set at 0.10 because they have a behavior of aggregating at reefs but extract food largely from the water column. A small credit is appropriate because the reef may provide some protection against predation for this group of fishes and may interact with currents to create better feeding opportunities.

\section{Discounting and scaling}

Our synthesis of data on how abundance of fish and large mobile crustaceans changes over time after creation of a restored oyster reef revealed that for reefs constructed in summer, development of fish and mobile crustacean abundance is virtually complete by the next spring-summer season. Densities do not increase in successive years (Grabowski 2002). The 0 age class that provides $92 \%$ of the enhancement of production by fish and mobile crustaceans exhibits densities in the summer after construction that are indistinguishable from densities in succeeding years. Furthermore, the fish community compositions and species abundances on oyster reefs restored 6 yr before sampling were largely indistinguishable from those on natural oyster reefs (Lenihan et al. 2001). Prey 
Table 5. Brief synopsis, including number of studies (out of 5) in which a species was collected, number of studies showing higher density of that species on oyster reefs (enhanced), range of enhancement index values (enhancement index), and group designation (grouping) from our synthesis of common fish and mobile crustaceans found on oyster reefs in the southeastern USA. See 'Materials and methods' for definitions of terms and procedures. ${ }^{*}$ Contradictory results across studies

\begin{tabular}{|c|c|c|c|c|c|}
\hline Species & $\begin{array}{l}\text { Common } \\
\text { name }\end{array}$ & $\begin{array}{l}\text { Collected } \\
\text { (no. of } \\
\text { studies) }\end{array}$ & $\begin{array}{l}\text { Enhanced } \\
\text { (no. of } \\
\text { studies ) }\end{array}$ & $\begin{array}{l}\text { Enhancement } \\
\text { Index }\end{array}$ & Grouping \\
\hline \multicolumn{6}{|l|}{ Large mobile crustaceans } \\
\hline Farfantepenaeus duorarum & Pink shrimp & 2 & 2 & All mudflat - all reef & Not enhanced \\
\hline Liptopenaeus setiferus & White shrimp & 1 & 1 & 1.89 & Not enhanced \\
\hline Farfantepenaeus aztecus & Brown shrimp & 1 & 0 & All mudflat & Not enhanced \\
\hline Callinectes sapidus & Blue crab & 5 & 1 & 0.2 - all reef & Not enhanced \\
\hline Menippe mercenaria & Stone crab & 4 & 3 & 0.8 - all reef & Recruitment enhanced \\
\hline \multicolumn{6}{|l|}{ Fish } \\
\hline Anchoa hepsetus & Striped anchovy & 1 & 0 & 0.1 & Not enhanced \\
\hline Anchoa mitchilli & Bay anchovy & 2 & 2 & $0.3-18$ & Growth enhanced \\
\hline Archosargus probatocephalus & Sheepshead & 2 & 2 & All reef & Recruitment enhanced \\
\hline Bairdiella chrysoura & Silver perch & 3 & 2 & All mudflat - all reef & Not enhanced \\
\hline Brevoortia patronus & Gulf menhaden & 1 & 0 & 1.0 & Not enhanced \\
\hline Brevoortia tyrannus & Atlantic menhaden & 2 & 0 & All mudflat -0.2 & Not enhanced \\
\hline Carcharhinus acronotus & Blacknose shark & 1 & 0 & All mudflat & Not enhanced \\
\hline Carcharhinus limbatus & Blacktip shark & 1 & 0 & All mudflat - 0.1 & Not enhanced \\
\hline Centropristis striata & Black sea bass & 2 & 2 & 0.5 - all reef & Growth enhanced \\
\hline Chaetodipterus faber & Atlantic spadefish & 1 & 0 & All sand - all reef & Not enhanced* ${ }^{*}$ \\
\hline Chasmodes bosquianus & Striped blenny & 4 & 4 & All reef & Recruitment enhanced \\
\hline Chilomycterus schoepfi & Striped burrfish & 1 & 0 & All mudflat & Not enhanced \\
\hline Cynoscion nebulosus & Speckled seatrout & 2 & 1 & All mudflat - all reef & Not enhanced* \\
\hline Cynoscion regalis & Weakfish & 1 & 1 & 0.4 - all reef & Not enhanced* ${ }^{*}$ \\
\hline Cyprinodon variegatus & Sheepshead minnow & w 1 & 1 & 0.5 - all reef & Growth enhanced \\
\hline Diplodus holbrooki & Spotail pinfish & 1 & 1 & 1.64 - all reef & Growth enhanced \\
\hline Eucinostomus argenteus & Spotfin mojarra & 1 & 0 & 0.33 & Not enhanced \\
\hline Fundulus heteroclitus & Mummichog & 3 & 1 & $0.32-$ all reef & Not enhanced \\
\hline Gobiesox strumosus & Skilletfish & 1 & 1 & All reef & Recruitment enhanced \\
\hline Gobionellus boleosoma & Darter goby & 2 & 0 & All mudflat - 1.5 & Not enhanced \\
\hline Gobiosoma bosci & Naked goby & 4 & 4 & $33-$ all reef & Recruitment enhanced \\
\hline Hypsoblennius hentz & Feather blenny & 1 & 1 & All reef & Recruitment enhanced \\
\hline Lagodon rhomboides & Pinfish & 4 & 1 & All mudflat - all reef & Not enhanced \\
\hline Leiostomus xanthurus & Spot & 5 & 1 & All mudflat - all reef & Not enhanced \\
\hline Lucania parva & Rainwater killifish & 2 & 1 & 1 - all reef & Not enhanced* \\
\hline Lutjanus griseus & Gray snapper & 2 & 2 & 4 - all reef & Recruitment enhanced \\
\hline Membras martinica & Rough silversides & 1 & 1 & 23 & Growth enhanced \\
\hline Menidia beryllina & Inland silversides & 1 & 1 & 4.1 & Growth enhanced \\
\hline Menidia menidia & Atlantic silversides & 1 & 1 & All reef & Growth enhanced \\
\hline Micropogonias undulatus & Atlantic croaker & 3 & 0 & All mudlfat - 1.2 & Not enhanced \\
\hline Monacanthus hispidus & Filefish & 1 & 0 & All mudflat - all reef & Not enhanced \\
\hline Morone americana & White perch & 1 & 1 & All reef & Growth enhanced \\
\hline Morone saxatilis & Striped bass & 1 & 1 & All reef & Not enhanced* ${ }^{*}$ \\
\hline Mugil cephalus & Striped mullet & 3 & 1 & All mudflat - all reef & Not enhanced \\
\hline Mugil curema & White mullet & 1 & 1 & 1.8 & Not enhanced* ${ }^{*}$ \\
\hline Mycteroperca microlepis & Gag grouper & 2 & 2 & 1 - all reef & Recruitment enhanced \\
\hline Opsanus spp. & Toadfishes & 4 & 4 & $0.4-$ all reef & Recruitment enhanced \\
\hline Orthopristis chrysoptera & Pigfish & 4 & 3 & All mudflat - all reef & Growth enhanced \\
\hline Paralichthys albigutta & Gulf flounder & 2 & 0 & All mudflat - 0.3 & Not enhanced \\
\hline Paralichthys dentatus & Summer flounder & 2 & 1 & All mudflat - all reef & Not enhanced \\
\hline Paralichthys lethostigma & Southern flounder & 2 & 2 & $1-3.3$ & Growth enhanced \\
\hline Peprilus spp. & Butterfish & 1 & 1 & All reef & Not enhanced $^{*}$ \\
\hline Pogonias cromis & Black drum & 1 & 0 & 0.66 & Not enhanced \\
\hline Pomatomus saltatrix & Bluefish & 2 & 0 & All mudflat - 0.5 & Not enhanced \\
\hline Sciaenops ocellatus & Red drum & 2 & 1 & All sand - all reef & Not enhanced* ${ }^{*}$ \\
\hline Scomberomorus maculatus & Spanish mackerel & 1 & 0 & All sand & Not enhanced \\
\hline Tautoga onitis & Tautog & 2 & 2 & 2 - all reef & Recruitment enhanced \\
\hline Trinectes maculatus & Hogchoker & 1 & 0 & All mudflat & Not enhanced \\
\hline
\end{tabular}


species abundances, both sessile benthic invertebrates on reefs and also small mobile crustaceans, also reached their natural densities on restored oyster reefs by the first spring-summer after a summer restoration (Grabowski 2002). One important prey species, the grass shrimp Paleomonetes pugio (in Wenner et al. 1996), exhibited higher densities on oyster reefs restored within the previous year than on nearby natural reefs. Consequently, we found no evidence that restoration of this ecosystem service requires more than a single year to be realized. Furthermore, the creation of a restored oyster reef does not enhance fishing pressure to a degree that would require adjustment of mortality rates of reef-dependent fishes, a factor that could conceivably require reduction of the estimated production credit assigned to the reef. The 0 -age-class recruits that comprise most of the enhanced production on oyster reefs (Tables $2 \& 4$ ) are not exploited.

The production credit attributable to the creation of a restored oyster reef is dependent on the functional lifetime of the reef. Because of the need to discount the value of future production, the cumulative production value discounted to present does not increase linearly. As reef lifetime increases, the rate of increase in cumulative value of production slows (Fig. 3). For our estimated annual production of $2.57 \mathrm{~kg} \mathrm{yr}^{-1}$, the discounted cumulative production credit for $20 \mathrm{yr}$ of reef function is $38.2 \mathrm{~kg} 10 \mathrm{~m}^{-2}$ of reef. For $30 \mathrm{yr}$, this credit increases to $50.4 \mathrm{~kg} 10 \mathrm{~m}^{-2}$. By $100 \mathrm{yr}$, an asymptote of ca. $80 \mathrm{~kg} 10 \mathrm{~m}^{-2}$ is approached (Fig. 3). Although highly variable as a consequence of unpredictable storm impacts, sedimentation, and appropriateness of site selection, a reasonable estimate for the functional lifetime of a restored oyster reef that is successfully protected from damage by bottom-disturbing fishing gear (Lenihan \& Peterson 1998, Lenihan \& Micheli 2000) ranges from 20 to $30 \mathrm{yr}$.

\section{DISCUSSION}

Our estimation of enhanced production of fish and large mobile crustaceans, attributable to replacing an area of unstructured mud/sand estuarine bottom in the southeast USA with a restored oyster reef, illustrates a process that combines review and synthesis of relevant empirical data bases, followed by application of appropriate basic concepts about limits on production of species at higher trophic levels in the system. The process is a generic one, analogous to what has been done to the scaling of restoration of seagrass habitat in terms of ecosystem benefits that flow from that action (Fonseca et al. 2000). We acknowledge uncertainty about the magnitude of estimates at all stages in this set of calcu-

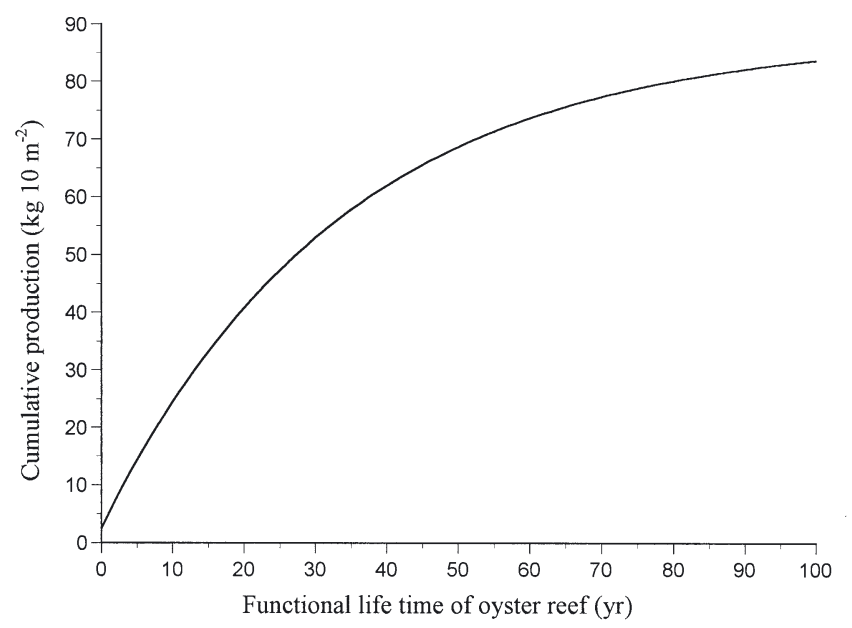

Fig. 3. Long-term projection of cumulative enhanced fish and mobile crustacean production per $10 \mathrm{~m}^{2}$ of restored oyster reef habitat, discounted to adjust for annual depreciation of resources as a function of the functional lifetime of the reef. An annual discount rate of $3 \%$ was applied

lations that lead to the fish and mobile crustacean production credit attributable to an area of restored oyster reef. However, we defend this calculation on the grounds that it makes use of extensive empirical data on restoration effectiveness and well-conceived, current conceptual understanding in fisheries ecology. Limitations in the data on rarer species that led us to exclude some species from the list of those enhanced by reef habitat contribute very little error to our estimate of total augmented production, because the rare species contribute so little to the sum. We do not include one indirect mechanism that may contribute further production benefits from oyster reef restoration. Oyster reefs tend to interfere with trawling and other bottom-disturbing fishing practices, such that if reefs are restored in areas where historic trawling operates, then their contribution to protection of benthic habitat may need to be included in the computation of production benefits.

Results of such scaling calculations are used by government resource agencies, most notably in the USA by NOAA, in legal settings to identify and provide for restoration, as the appropriate remedy for unlawful injuries to natural resources (NOAA 1997). More broadly, however, this estimate of one important ecosystem service of oyster reefs can be used by resource and coastal managers to make decisions about estuarine management and habitat restoration for a habitat that has declined over the past century by around 2 orders of magnitude in the Chesapeake Bay and Pamlico Sound (Rothschild et al. 1994, Lenihan \& Peterson 1998), and has essentially disappeared from other estuaries in the northeast USA, west coast of 
North America, Adriatic, and elsewhere around the world (Jackson et al. 2001). Valuation of fish production derived from oyster reefs is also central to efforts to define and then protect essential fish habitat (Coen \& Luckenbach 2000).

Our estimate of the added value of restoring oyster reefs as measured by production of fish and large mobile crustaceans should be viewed as a quantitative prediction. Testing is feasible, although it would require a spatial scale appropriate to the mobility of the species to allow isolation of treatments, and controls and establishment of a well conceived a priori plan to couple the project with its evaluation (e.g. Lindberg \& Relini 2000, Hobbs \& Harris 2001). Treatment of uncertainty in restoration and mitigation projects is an important concern to provide guarantees that resources and their services are indeed replaced. Uncertainty can be incorporated in 2 fundamentally different fashions. One approach is to establish and apply a mitigation ratio such that restored habitat is made greater than the amount expected to be necessary for full replacement of lost value (e.g. Thayer 1992). This expansion of scale incorporates uncertainty of success, with ratios increasing as uncertainty increases. An alternative approach is to monitor the restoration project carefully and modify it adaptively as needed to meet the quantitative target of restoration (e.g. Ambrose \& Swarbrick 1989). The adaptive management approach has the added value of providing information that can test the prediction and enhance understanding to improve future predictions and reduce uncertainty for future applications. Nevertheless, parties held responsible for restoring the lost ecosystem services typically dislike the open-ended nature of the adaptive management commitment, and prefer a fixed level of effort, as reflected in the mitigation-ratio approach.

Realized success in enhancing fish production through oyster reef restoration will depend on many variables that influence oyster reef function. Our calculations apply to a generic oyster reef in the southeastern USA, an approach dictated by the small number of data sets preventing incorporation of modifying covariates. Such covarying factors mostly involve decisions about site selection and design criteria for the reef restoration. The landscape setting in which a reef is placed dictates the ability of many higher-level consumers to utilize it. For example, intertidal oyster reefs placed adjacent to salt marshes or adjacent to subtidal seagrass beds, rather than in isolation from other structured habitats, vary in their functioning by supporting different patterns of fish and crab utilization (Meyer et al. 1996, Irlandi \& Crawford 1997, Micheli \& Peterson 1999, Grabowski 2002). Intertidal and subtidal oyster reefs are likely to differ in value to fish and mobile crustaceans largely because of the need to find alternative submerged refuge at low tide. This consideration also implies that landscape setting may impact intertidal more than subtidal reef function. The choice of whether to construct a few reefs large in area or several smaller ones can affect fish utilization through modification of perimeter-to-area ratios and, thus, proportions of edges with their intrinsically higher access to mobile consumers. Networks of oyster reefs built along environmental gradients can provide refuges for fish escaping environmental degradation and thus serve to enhance fish production more than a design that isolates reefs in a single environmental regime (Lenihan et al. 2001). Because of extensive depletion of spawning stock biomass in some estuaries, siting oyster reefs where larval settlement is reliable enough to sustain oyster populations is crucial, often involving the need to understand hydrodynamic setting and locations of retention cells (Coen \& Luckenbach 2000, Mann 2000). Decisions made about reef design, including height and water depth (Lenihan \& Peterson 1998), shape, composition of reef material, prevailing water flow regime, and stability of underlying sediments (Luckenbach et al. 1999), all help to determine the success of achieving restoration goals.

Given that oyster reefs provide many ecosystem services beyond enhancing production of fishes and large mobile crustaceans, there are additional environmental benefits achieved by reef restoration. These include positive effects on water clarity, carbon sequestration, rate of denitrification, and oyster restocking. We do not attempt to quantify the value of these other attendant ecosystem services, largely because the currency of benefits is not comparable to the measure used in this analysis (i.e. production of fish and mobile crustaceans at high trophic levels). We chose this particular currency to match the benefit of restoration with the loss in a fundamental ecosystem service, production of fish and mobile crustaceans. The environmental incident, an acidic process water spill, which caused the loss of fish and mobile crustaceans (French 1999), clearly must have had impacts on other components of the Alafia River ecosystem. To characterize those losses fully would involve tremendous commitment of resources. For the sake of administrative simplicity and cost effectiveness, only some of the injuries to ecosystem services were estimated in this and other incidents. When compensation for those measured injuries to natural resources is achieved by habitat restoration like oyster reef creation, then one can be confident that many other ecosystem services will be simultaneously provided to help replace those that were injured, but not studied or quantified. This approach assumes that many ecosystem services scale linearly to one another. That does not seem an unreasonable assumption, yet it 
also deserves rigorous testing. Independent of whether restoration of some ecosystem services is more complete than others, this approach of habitat restoration is likely to provide greater ecosystem benefits than an alternative program of species-by-species restoration at the population level. Habitat degradation is widely recognized as the greatest cause of species declines (e.g. Soule 1986), so its restoration deserves highest priority in conservation programs and in mitigation efforts.

Acknowledgements. We express appreciation to the investigators of the 6 studies used in this synthesis. The paper benefited from the comments of D. Breitberg, M. Carr, M. Hixon, R. Kneib, P. Levin, C. Manen, G. Stunz, R. Wolotira, and 2 referees in refining the conceptual approach used in this synthesis. D. French checked and rechecked all of our production and scaling calculations. L. Dipinto, B. Julius, and T. Penn provided guidance. The NOAA Damage Assessment Center provided funding for this synthesis and publication, with additional basic research support from Environmental Defense, and the NOAA NERRS Program.

\section{LITERATURE CITED}

Abraham BJ (1985) Species profiles: life histories and environmental requirements of coastal fish and invertebrates (Mid Atlantic)-mummichog and killifish. Biological Report 82 (11.40), US Fish and Wildlife Service. US Army Corps of Engineers, TR EL-82-4, Vicksburg, MS

Allen EB, Covington WW, Falk DA (1997) Developing a conceptual basis for restoration ecology. Restor Ecol 5:275

Ambrose RF, Swarbrick SL (1989) Comparison of fish assemblages on artificial and natural reefs off the coast of southern California. Bull Mar Sci 44:718-733

Bahr LM, Lanier WP (1981) The ecology of intertidal oyster reefs of the South Atlantic coast: a community profile. Report No. FWS/OBS-81/15, Office of Biological Services, US Fish and Wildlife Service, Slidell, LA

Bohnsack JA (1989) Are high densities of fishes at artificial reefs the result of habitat limitation or behavioral preference? Bull Mar Sci 44:631-645

Botsford LW, Castilla JC, Peterson CH (1997) The management of fisheries and marine ecosystems. Science 277 : 509-515

Breitburg DC (1999) Are three-dimensional structure and healthy oyster populations the keys to an ecologically interesting and important fish community? In: Luckenbach MW, Mann R, Wesson JA (eds) Oyster reef habitat restoration: a synopsis and synthesis of approaches. Virginia Institute of Marine Science Press, Gloucester Point, VA, p 239-250

Brown BE, Browder JA, Powers J, Goodyear CD (1990) Biomass, yield models, and management strategies for the Gulf of Mexico ecosystem. Southeast Fisheries Science Center, National Marine Fisheries Service, NOAA, Miami, FL

Carpenter SR, Kitchell JF (1993) The trophic cascade in lakes. Cambridge University Press, Cambridge

Coen LD, Luckenbach MW (2000) Developing success criteria and goals for evaluating oyster reef restoration: ecological functioning or resource exploitation? Ecol Engineer 15: $323-343$
Coen LD, Luckenbach MW, Breitburg DL (1999) The role of oyster reefs as essential fish habitat: a review of current knowledge and some new perspectives. In: Benaka LR (ed) Fish habitat: essential fish habitat and restoration, Am Fish Soc Symp 22:438-454

Dame RF (1996) Ecology of bivalves. CRC Press, Boca Raton, FL

Doherty PJ, Williams DMcB (1988) The replenishment of coral reef fish populations. Oceanogr Mar Biol Annu Rev 26: 487-551

Fonseca MS, Julius BE, Kenworthy WJ (2000) Integrating biology and economics in seagrass restoration: how much is enough and why? Ecol Engineer 15:227-237

French DP (1999) Estimating injuries resulting from the December 1997 process water spill into the Alafia River. Final Report, NOAA, Damage Assessment Center, Silver Spring, MD

French DP, Rines H, Keller A, French FW III, Gifford D, Pavignano S (1997) The CERCLA type A natural resource damage assessment model for coastal and marine environments. Technical Documentation Volume IV Biological Database Part 1, Office of Environmental Policy and Compliance, US Dept of the Interior, Washington, DC

Goodyear CP (1988) Spawning stock biomass and yield per recruit for several reef fish species of the Gulf of Mexico. Southeast Fisheries Science Center, NOAA, Miami, FL

Goodyear CP, Schirripa MJ (1991) A biological profile for vermilion snapper with a description of the fishery in the Gulf of Mexico. Southeast Fisheries Science Center, NOAA, Miami, FL

Grabowski JH (2002) The influence of trophic interactions, habitat complexity, and landscape setting on community dynamics and restoration of oyster reefs. PhD thesis, University of North Carolina at Chapel Hill, Chapel Hill, NC

Harding JM, Mann R (1999) Fish species richness in relation to restored oyster reefs, Piankatank River, Virginia. Bull Mar Sci 65:289-300

Hargis WJ Jr, Haven DS (1999) Chesapeake oyster reefs, their importance, destruction and guidelines for restoring them. In: Luckenbach MW, Mann R, Wesson JA (eds) Oyster reef habitat restoration: a synopsis of approaches. Virginia Inst Mar Sci Press, Gloucester Point, VA, p 329-358

Hixon MA (1998) Population dynamics of coral-reef fishes: controversial concepts and hypotheses. Aust J Ecol 23:192-201

Hobbs RJ, Harris JA (2001) Restoration ecology: repairing earth's ecosystems in the new millennium. Restor Ecol 9: $239-246$

Hood PB, Schlieder RE (1992) Age, growth, and reproduction of gag, Mycteroperca microlepis (Pisces: Serranidae), in the eastern Gulf of Mexico. Bull Mar Sci 51:337-352

Irlandi EA, Crawford MK (1997) Habitat linkages: the effect of intertidal salt marshes and adjacent subtidal habitats on abundance, movement, and growth of an estuarine fish. Oecologia 110:222-230

Jackson JBC, Kirby MX, Berger WH, Bjorndal KA and 14 others (2001) Historical overfishing and the recent collapse of coastal ecosystems. Science 293:629-638

Jordan WR, Gilpin ME, Aber JD (1987) Restoration ecology. Cambridge University Press, Cambridge

Krantz GE, Jordan SJ (1996) Management alternatives for protecting Crassostrea virginica fisheries in Perkinsus marinus enzootic and epizootic areas. J Shellfish Res 15:167-176

Lawton JH (1996) Corncake pie and prediction in ecology. Oikos 76:3-4

Lenihan HS, Micheli F (2000) Biological effects of shellfish harvesting on oyster reefs: resolving a fishery conflict using ecological experimentation. Fish Bull 98:86-95 
Lenihan HS, Peterson CH (1998) How habitat degradation through fishery disturbance enhances impacts of hypoxia on oyster reefs. Ecol Appl 8:128-140

Lenihan HS, Grabowski JH, Thayer GW (1998) Recruitment to and utilization of oyster reef habitat by commercially and recreationally valuable crabs and fishes: an experiment with economic analysis. Final Report No. 1-97, National Research Council. National Marine Fisheries Service, Beaufort, NC

Lenihan HS, Micheli F, Shelton SW, Peterson CH (1999) The influence of multiple environmental stressors on susceptibility to parasites: an experimental determination with oysters. Limnol Oceanogr 44:910-924

Lenihan HS, Peterson $\mathrm{CH}$, Byers JE, Grabowski JH, Thayer GW, Colby D (2001) Cascading of habitat degradation: oyster reefs invaded by refugee fishes escaping stress. Ecol Appl 11:746-782

Lewis RR, Estevez ED (1988) The ecology of Tampa Bay, Florida: an estuarine profile. Biological Report 85 (7.18), US Fish and Wildlife Service, Vicksburg, MS

Lindberg WJ, Marshall MJ (1984) Species profiles: life histories and environmental requirements of coastal fishes and invertebrates (south Florida) - stone crab. Report No. FWS/OBS-82/11.21, US Fish and Wildlife Service. US Army Corps of Engineers, TR EL-82-4, Vicksburg, MS

Lindberg WJ, Relini G (2000) Integrating evaluation into reef project planning. In: Seaman WJ Jr (ed) Artificial reef evaluation with application to natural marine habitats. CRC Press, Boca Raton, FL, p 195-235

Lindquist DG, Cahoon LB, Clavijo IE, Posey MH, Bolden SK, Pike LA, Burk SW, Cardullo PA (1994) Reef fish stomach contents and prey abundance on reef and sand substrata associated with adjacent artificial and natural reefs in Onslow Bay, North Carolina. Bull Mar Sci 55:308-318

Livingston RJ (1984) The ecology of the Apalachicola Bay system: an estuarine profile. Report No. FWS/OBS 82.05, US Fish and Wildlife Service, Slidell, LA

Livingston RJ (2001) Eutrophication processes in coastal systems: origin and succession of plankton blooms and effects on secondary production in Gulf Coast estuaries. CRC Press, New York, NY

Livingston RJ, Howell RL, Niu X, Lewis FG, Woodsum GC (1999) Recovery of oyster reefs (Crassostrea virginica) in a gulf estuary following disturbance by two hurricanes. Bull Mar Sci 64:465-483

Luckenbach MA, Mann R, Wesson JE (eds) (1999) Oyster reef restoration: a symposium and synthesis of approaches. Virginia Inst Marine Sci Press, Gloucester Point, VA

Mann R (2000) Restoring oyster reef communities in the Chesapeake Bay: a commentary. J Shellfish Res 19: 335-340

Mann R, Harding JM (1997) Trophic studies on constructed 'restored' oyster reefs. Grant/Contract No. CB993267-02-1, US Environmental Protection Agency, Chesapeake Bay Program Office, Annapolis, MD

Mann R, Harding JM (1998) Continuing trophic studies on constructed 'restored' oyster reefs. Grant/Contract No. CB993267-03, US Environmental Protection Agency, Chesapeake Bay Program Office, Annapolis, MD

Manooch CS, Haimovici M (1978) Age and growth of the gag, Mycteroperca microlepis, and size-age composition of the recreational catch off the southeastern United States. Trans Am Fish Soc 107:234-240

Manooch CS, Mason DL (1984) Age, growth, and mortality of lane snapper from Southern Florida. Northeast Gulf Sci 7: 109-115

Meyer DL, Townsend EC, Murphy PL (1996) The evaluation of restored wetlands and enhancement methods for existing restorations. Final Report, Office of Habitat Conservation, NOAA, Silver Spring, MD

Micheli F, Peterson CH (1999) Estuarine vegetated habitats as corridors for predator movements. Conserv Biol 13: 869-881

Middaugh DP, Hemmer MJ (1992) Reproductive ecology of the inland silverside, Menidia beryllina, (Pisces: Atherinidae) from Blackwater Bay, Florida. Copeia 1992:53-61

Millikin MR, Williams AB (1984) Synopsis of biological data on the blue crab, Callinectes sapidus Rathbun. NOAA Technical Report NMFS 1 FAO Fisheries Synopsis No. 138. US Dept of Commerce, NOAA, NMFS, Washington, $\mathrm{DC}$

Newell RIE (1988) Ecological changes in the Chesapeake Bay: are they the result of overharvesting the American oyster, Crassostrea virginica? In: Lynch MP, Krome EC (eds) Understanding the estuary: advances in Chesapeake Bay research. Publication No. 129 CBP/TRS 24/88, Chesapeake Bay Research Consortium, Gloucester Point, VA, p 536-546

Newell RIE, Cornwell JC, Owens MS (2002) Influence of simulated bivalve biodeposition and microphytobenthos on sediment nitrogen dynamics: a laboratory study. Limnol Oceanogr 47:1367-1379

NOAA (National Oceanographic and Atmospheric Administration) (1997) Habitat equivalency analysis: an overview. Policy and Technical Paper Series, No 95-1. Damage Assessment and Restoration Program, NOAA, Silver Spring, MD

O'Beirn FX, Luckenbach MW, Mann R, Harding J, Nestlerode $\mathrm{J}$ (1999) Ecological functions of constructed oyster reefs along an environmental gradient in Chesapeake Bay. Virginia Inst Mar Sci, Gloucester Point, VA

Palmer MA, Ambrose RF, Poff NL (1997) Ecological theory and community restoration ecology. Restor Ecol 5:291-300

Peterson CH (1993) Improvement of environmental impact analysis by application of principles derived from manipulative ecology: lessons from coastal marine case histories. Aust J Ecol 18:21-52

Peterson CH, Black R (1994) An experimentalist's challenge: when artifacts of intervention interact with treatments. Mar Ecol Prog Ser 111:289-297

Rothschild BJ, Ault JS, Goulletquer P, Héral M (1994) Decline of the Chesapeake Bay oyster population: a century of habitat destruction and overfishing. Mar Ecol Prog Ser 111:29-39

Rozas LP (1992) Bottomless lift net for quantitatively sampling nekton on intertidal marshes. Mar Ecol Prog Ser 89: $287-292$

Savage T, Sullivan JR (1978) Growth and claw regeneration of the stone crab, Menippe mercenaria. Florida Dept of Natural Resources, St. Petersburg, FL

Serafy JE, Hopkins TE, Walsh PJ (1997) Field studies on the ureogenic gulf toadfish in a subtropical bay. I. Patterns of abundance, size composition and growth. J Fish Biol 50: $1258-1270$

Sheaves MJ (1992) Patterns of distribution and abundance of fish in different habitats of a mangrove-lined tropical estuary, as determined by fish trapping. Aust J Mar Freshw Res 43:1461-1479

Soule M (ed) (1986) Conservation biology. Sinauer, Sunderland, MA

South Atlantic Fishery Management Council (1983) Fishery management plan, regulatory impact review, and final environmental impact statement for the snapper-grouper fishery of the south Atlantic region. South Atlantic Fishery Management Council, NMFS, Charleston, SC 
Sullivan JR (1979) The stone crab, Menippe mercenaria, in the southwest Florida fishery. Florida Marine Research Publications Number 36. Marine Research Lab, Florida Dept of Natural Resources, St. Petersburg, FL

Thayer GW (ed) (1992) Restoring the nation's marine environment. Maryland Sea Grant College Program, College Park, MD

van Diggelen R, Grootjans AP, Harris JA (2001) Ecological restoration: state of the art or state of the science? Restor Ecol 9:115-118

Vitousek PM, Mooney HA, Lubchenco J, Mellilo J (1997) Human domination of earth's ecosystems. Science 277:494-499

Wells HW (1961) The fauna of oyster reefs with special reference to the salinity factor. Ecol Monogr 31:239-266

Wenner E, Beatty HR, Coen LD (1996) A method for quantita- tively sampling nekton on intertidal oyster reefs. J Shellfish Res 15:769-775

Wilson CA, Dean JM, Radtke R (1982) Age, growth rate and feeding habits of the oyster toadfish, Opsanus tau (Linnaeus) in South Carolina. J Exp Mar Biol Ecol 62:251-259

Wilson EO (1992) Diversity of life. Harvard University Press, Cambridge, MA

Zimmerman RJ, Minello TJ, Zamora G, Martinez E (1986) Measurements of estuarine shrimp densities applied to catch predictions. In: Landry AM, Kilma EF (eds) Proc Shrimp Yield Prediction Workshop. Texas A\&M Sea Grant College Program, Galveston, TX, p 37-55

Zimmerman RJ, Minello TJ, Baumer T, Castiglione M (1989) Oyster reef as habitat for estuarine macrofauna. Tech Memm NMFS-SEFC-249, NOAA, Galveston, TX

Appendix 1. Calculation of enhanced fish production for sheepshead. Equations and symbols can be found in the 'Materials and methods' section. All necessary parameters for the calculations (survival rates, age-length, length-weight) appear in Table 3

\begin{tabular}{|c|c|c|c|c|c|c|c|}
\hline$i$ & $S_{i}$ & $S x_{i}$ & $N_{i}$ & $L_{i}$ & $W_{i}$ & $P_{i}$ & $P_{i} \times N_{i}$ \\
\hline 0 & 1 & & & & & & \\
\hline 1 & 0.819 & 0.819 & 1.040 & 18.306 & 152.907 & 152.907 & 159.023 \\
\hline 2 & 0.670 & 0.819 & 0.851 & 23.272 & 311.171 & 158.264 & 134.759 \\
\hline 3 & 0.549 & 0.819 & 0.697 & 27.318 & 500.093 & 188.921 & 131.703 \\
\hline 4 & 0.301 & 0.549 & 0.383 & 30.614 & 700.619 & 200.526 & 76.719 \\
\hline 5 & 0.165 & 0.549 & 0.210 & 33.299 & 898.577 & 197.958 & 41.565 \\
\hline 6 & 0.091 & 0.549 & 0.115 & 35.486 & 1084.776 & 186.199 & 21.456 \\
\hline 7 & 0.050 & 0.549 & 0.063 & 37.268 & 1254.072 & 169.296 & 10.706 \\
\hline 8 & 0.027 & 0.549 & 0.035 & 38.720 & 1404.248 & 150.175 & 5.212 \\
\hline 9 & 0.015 & 0.549 & 0.019 & 39.902 & 1535.033 & 130.785 & 2.491 \\
\hline 10 & 0.008 & 0.549 & 0.010 & 40.866 & 1647.348 & 112.315 & 1.174 \\
\hline 11 & 0.005 & 0.549 & 0.006 & 41.651 & 1742.765 & 95.418 & 0.547 \\
\hline 12 & 0.002 & 0.549 & 0.003 & 42.290 & 1823.147 & 80.382 & 0.253 \\
\hline 13 & 0.001 & 0.549 & 0.002 & 42.811 & 1890.416 & 67.268 & 0.116 \\
\hline 14 & 0.001 & 0.549 & 0.001 & 43.235 & 1946.415 & 55.999 & 0.053 \\
\hline Total & & & 3.435 & & & & 585.779 \\
\hline
\end{tabular}

Editorial responsibility: Ronald Kneib, Sapelo Island, Georgia, USA
Submitted: September 18, 2001; Accepted: October 31, 2003 Proofs received from author(s): November 27, 2003 